\title{
Internal Marketing in Its Influence on Organizational Commitment: the Mediation of Job Satisfaction and Organizational Justice
}

\author{
USWATUN CHASANAH \\ Department of Management \& Business, \\ STIE Widya Wiwaha \\ Jl.Lowanu UH VI No.20 Yogyakarta 55162 \\ INDONESIA \\ M. SUYANTO \\ Department of Management \& Business, \\ Universitas AMIKOM \\ J1.Padjajaran, Ring Road Utara, Condongcatur, Sleman, Yogyakarta 55283 \\ INDONESIA \\ YUNI ISTANTO \\ Department of Management \& Business \\ Universitas Pembangunan Nasional \\ Jl.Padjajaran, Ring Road Utara, Condongcatur, Sleman, Yogyakarta 55283 \\ INDONESIA
}

\begin{abstract}
This research aims to examine organizational commitment model of private university lecturers in Indonesia, using three independent variables, namely internal marketing, job satisfaction and organizational justice. Data collection was done by survey method on 200 private university (PTS) lecturers under the Higher Education Service Institutions covering 14 regions in Indonesia. Helped by PLS (Partial Least Square), SEM (Structural Equation Model) was used to process the data collected. Accordingly, to check the validity, the measurement model was evaluated based on several reflective indicators (convergent and discriminant validity as well as composite reliability). Based on the result of discriminant and convergent validity, it is known that the whole constructs are valid as both the outer loading and AVE (Average Variance Extracted) value are $>0.70$, moreover, a similar good result shown in composite reliability evaluation with the value of $>0.70$. Finally, the results found showed that seven hypotheses, out of nine hypotheses, were proven to be true. On the other hand, for the other hypotheses, the findings showed that organizational justice and Internal marketing had no direct effect on organizational commitment. Next, it is also known that organizational justice and job satisfaction were proven to be the mediators of in the relation between internal marketing and organizational commitment.
\end{abstract}

Keywords: Organizational commitment, job satisfaction, organizational justice, internal marketing.

Received: December 4, 2020. Revised: April 7, 2021. Accepted: April 17, 2021. Published: April 21, 2021. 


\section{Introduction}

Organizational commitment is one of the issues that widely researched today in various disciplines including psychology, sociology, organizational behavior, accounting, socio-politics as well as marketing science. The concept of organizational commitment was first put forward in the field of political sociology [1], the field of organizational sociology [2]. The rationale for the field of political sociology comes from his analysis of political partisans and the deviant behavior of various members of society who question why there are political partisans who are so loyal to political parties. The research also examined what influences teachers so that they are reluctant to change jobs while there is the behavior of employees who frequently change companies [1].

Some researches on the study of organizational commitment from a social point of view that examines commitment from a societal perspective with an organizational focus, shows the desire of society to provide energy and loyalty to social systems [3], while other studies stated that commitment as awareness of the impossibility of choosing different social identities in society under bond strength [4]. In the 1970s, organizational commitment was conceptualized in, studied in, and addressed to the context of human attachment to organizations [5]. However, there was also a study administered to study internal marketing from the perspective of organizational commitment combined with employee satisfaction. It was shown from these studies that, to increase customer loyalty and satisfaction, service oriented deportment can be fostered through strong organizational commitment by implementing internal marketing praxis [6].

In an organizational context, investigations of internal marketing practices were done through empirical studies, including internal marketing adoption level in organizations [7], [8], internal marketing practices on functional strategy implementation [9], internal marketing at the organizational level [10], organizational commitment in its role to intervene the quality of service and internal marketing[10], [11]. In the same context, for tourism companies, cultural congruence also studied as the moderator of job contentment of employee and internal marketing[12]. Similar to those studies, this study also proved empirically that the development of job satisfaction quality runs in line with internal marketing benefaction. As the job satisfaction increased, then, organizational performance will do as well. Thus, it can be safely concluded that internal marketing can be used to increase job satisfaction in an organization [13]. Another benefit of having well satisfied employee is its impact on organizational commitment [14]. In other words, it can be also said that, in an organization, the more Job satisfaction employees have, the better their commitment to perform well [15].

A bunch of previous researches on that matter [16] showed that the employees contentment towards a job will play the role of a precursor affecting their commitment in an organization. a pleasant emotional state, so called Job satisfaction will come by appraising one's work experience or job. This idea positions job satisfaction from an affective view related to one's emotions [17]. The contentment is directly affected by cognitive and affective perception of an individual. In this term, one's job satisfaction assessment is able to trigger determinate affective satisfaction or vice versa [18].

Positive or negative emotional satisfaction is related to acceptance of organizational justice. Substantially, it acts as a fundamental contributing to job satisfaction and organizational commitment development. In its function, organizational justice is crucial for organizations as well as society since organizational justice perceptions affect one's behavior, opinions, and feelings towards anorganization [19]. the higher the justice an organization has (in term of wages, job promotion and performance appraisal), the higher commitment employees will have towards an organization. Meanwhile, any kind of inequality and injustice perception brings job dissatisfaction and its, of course, one of the unwanted as it results in lower performance, organizational distrust, delays in career development, and any other kinds of organizational negativity. As a crucial determinant giving influence to job satisfaction, oganizational justice should be well maintained. The level of job satisfaction indicates the effectiveness of organizational justice implementation[20].

Accordingly, several studies were done to seek the truth behind organizational justice implementation in raising job satisfaction. One of which found that the is positivity in the relation of job satisfaction and organizational justice[21]. The quality of an implementation of organizational justice depicts perceptions toward the treatment. In this case, satisfaction is merely a reaction towards the justice enforced [22]. Employees tend to be content with the job along with fair treatment, well valued work having been done, well rewarded for achievements, or any other kinds of appreciations. High job satisfaction will boost the morale of employees to believe that an organization will have 
a bright future (in long term). As this condition achieved, they tend commit more for the organization welfare, more productive and more likely to be loyal [23].

Particulary, organizational justice has a direct relation to employees perception, in terms of work performance, if they are fairly treated and to how the determination in reinforcing organizational justice influence other work-related issues [24]. It also explains employees response towards the treatment in interactions and processes [25]. Organizational justice models (procedural, interactional, and distributive justice) were studied in a research, it was found that these dimensions of organizational justice, significantly, affect employees contentment in job [24]. In similar context, another research also found that satisfaction and organizational commitment are closely related to perceptions towards the enforced justice (Moorman et al., 1998). The findings are in line with another study showing that organizational justice is the precursor of performance quality level as well as satisfaction; and job satisfaction is the precursor of organizational commitment [27].

Accordingly, taking references from previous discussions, this study was intended to investigate internal marketing in its role to influence organizational commitment with organizational justice and employee satisfaction as mediating variables to the implementation of internal marketing in private universities in Indonesia and how it influences the organizational commitment of lecturers in the private universities.

Accordingly, this study was designed to examine the influential relation between internal marketing and organizational commitment via job satisfaction and organizational justice mediation. the study process was conducted contextually for internal marketing praxis in private universities (PTS) in Indonesia.

\section{Literature Review}

\subsection{Internal Marketing}

For more than 20 years, academics and practitioners question the concept of internal marketing, and there are pros and cons circulated. From an epistemological point of view, internal marketing is a social construct [28] in a specific context. It was first introduced with the concept of "work as a product and employees as internal customers" [29]. The debates on the construct of internal marketing can be seen from the 42 definitions existed over the past three decades [30]. Internal marketing is claimed as a mean for strategic consonance and cultural construct between marketing and front line staffs [31]. Views in internal marketing regard it as a set of procedural and political human resource positioning employees as needing information, development, and motivation to, effectively, serve and satisfy customers [32].

The internal marketing study is developed into three phases (employee satisfaction, customer orientation and implementation of strategy/ management changes). In the initial phase, most of the internal marketing literature focuses on internal marketing on issues of motivation and employee satisfaction. Employee satisfaction is said to be fundamental constituent influencing customer satisfaction [33]. Internal marketing theory positions employees as internal customers, and jobs as products affecting satisfactions toward expectations and needs of those "internal customers" in reaching organizational objectives. The philosophy of positioning employees as customers and work-related settings as products works as a mirroring phase. This phase will potentially affect the level of service quality provided for the actual customers during the transaction process [34].

The second phase is the consumer orientation phase (interactive marketing), or the customer orientation approach. The argument put forward is that buyer-seller interactions do not only affect purchase and repurchase decisions, but more importantly this relationship provides market opportunities for the organization. To get this opportunity, it requires customer-oriented employees and sales-oriented employees [35]. Furthermore, employees are not only encouraged to perform well, but also set a sales-oriented mind [36]. Therefore, internal marketing goals in this phase motivate and make employees cognizant of customers account for the organization.

Next, internal marketing is extensively defined as a motivation to be conscious of customers and sales into marketing activities. This requires effective coordination between employees having direct contact to the customers and supporting employees [37]. The concept of internal marketing also means integrating different and vital functions to serve customers. This concept focuses on creating employees to be customer-oriented rather than employee satisfaction and motivation [35]. Furthermore, entering the third phase is called the implementation strategy phase. This phase is characterized by an overview of internal marketing from a number of researchers who explicitly acknowledge internal marketing as a means of 
implementing strategy [33], [38], [39]. The majority of this researcher's opinion is due to the limitations of previous internal marketing concepts. The limitations that arise with the previous concept are first, unlike the external marketing situation where external customers can choose the products they will buy, employees positioned as customers cannot choose products in this job as they want. Second, employees must be able and, if necessary, forced to accept products (jobs) even though they do not want to, third, the priority in fulfilling the needs of employees as customers and the actual customers will probably be overlapping [9]. Most critics view it as a managerial perspective, viewing employees as internal customers with less concern but more desire to control [28]. The view of internal marketing is broadened as either internal social process management, marketing relationship, or management relationship. The general view is argued to acknowledge political power role on differential standpoint among employees and managers [40].

The accretion of conviction related to potentials of internal marketing as cross-functional integrated instrumentation within anorganization supports its development as an applied strategy. Internal marketing as something holistic involves a management process to integrate various functions within the organization [41]. This view is expressed by emphasizing internal marketing role in the integration of employees and marketing implementation in human resources into the marketing function [42].

The role of internal marketing as a strategy implementation tool that is designed explicitly appears in service marketing, that internal marketing as a strategic tool when it is implemented effectively will become a necessity to resolve conflicts between functions and it becomes a necessity to improve better internal communication [43]. This concept was further developed [44]. Internal marketing can be implemented in various organizations, not only service organizations but can be applied to manufacturing companies [45], internal marketing flows as a mechanism to reduce isolation between departments [46], internal marketing can reduce friction between functions in organization and reduce resistance to change, whereas internal marketing is also applied in the context of change management [47]. Discussions in this phase expand the scope of internal marketing beyond just motivating employees to be customer and sales oriented.

Based on reviews and definitions of internal marketing that developed in these phases as well as conceptual and empirical studies, there are internal marketing criteria known as employee satisfaction and motivation, customer satisfaction and orientation, coherency between integrations and functions. As a functional levels and an organizational strategic implementation [47], internal marketing modifies both coherency between tactical extents and functions [37] as well as marketing methodology [9]. In a practical definition, internal marketing can be seen as marketing approach used, strategically, to overcome counteraction to transformation by coordinating, motivating and integrating functions through organizational and functional strategies in satisfying customers in the process of shaping employees with good quality of service [9].

H1: Internal marketing influences organizational justice.

H2: Internal marketing influences job satisfaction.

H3: Internal marketing influences organizational commitment.

H4: Internal marketing influences organizational commitment through organizational justice.

H5: Internal marketing influences affects job satisfaction through organizational justice.

\subsection{Job Satisfaction}

One of the definitions, defines job satisfaction as a set of environmental, physiological, and psychological state of affairs. Based on this, there is internal process of how employees react to factors causing the satisfied feeling although it is functioned under the influence of external factors.

This is an optimistic affection towards a job based on certain characteristics appraisal. Such positivity only espouses those with high job satisfaction content but not for those without such content. These characteristics include many factors, including co-workers, working conditions, salary, work culture, career, relationships with superiors, and so on. A person's assessment of his / her satisfaction at work is very complex, influenced by many variables [48].

Research shows that the level of job satisfaction varies widely, in general, people are more satisfied with their work, both with the job itself, superiors and coworkers than with salary and promotion opportunities. According to a study, it is known that the countries with the highest job satisfaction levels are Mexico and Switzerland, while the lowest job satisfaction in South Korea is due to the rigidity of the business structure in South Korea and the lack of autonomy for workers. Current South Korean culture exists between traditional and contemporary cultural influences. 
Businesses that adhere to confusional values that still respect parents and centralized decisionmaking authority are obstacles in today's decentralized business competition. Another factor is the number of exposures received which results in various ways of life. South Korea has the highest percentage of subscribed to wireless broadband internet of all countries, showing that South Korean people have access to contemporary world business practices. Therefore, South Korean workers are aware of autonomy, value-based rewards and other benefits received by workers in other countries that they do not receive in South Korea. As in Mexico as one of the countries with high job satisfaction, it can be indicated that they still have better jobs for their workers and workers are more satisfied because they do not have opportunities for outside exposure. Workers who are satisfied at work will potentially more productive and commit more to organization welfare. Effective and better performance are bestowed upon oganizations full of satisfied workers. They also tend to be able to increase external customer satisfaction and loyalty [48].

In an organization, job satisfaction is seen as notable element of success. Many studies were carried out to increase worker job satisfaction in various sectors such as hospitality sector [49], governmental sector [50], non-profit sector [51], car manufacturing sector [52], and academic sector [53], [54].

In academic sector, there was a specified study examined the factors, benefitting two-factor theory of Herzberg, being able to gauge faculty job satisfaction in two major Malaysian universities. It found that, for faculty members; amount of salary, campus policies, and system of administration are factors influencing their job satisfaction. Furthermore, it was also found that low personal accession, late individual growth, bad working relationships, low level of acknowledgement, over duty, too strict monitoring, and unsupportive working environment can lead to job dissatisfaction [54].

Referring to previous findings, it can be said that job satisfaction of a faculty member is related to many complex causes, such as demographic character, type of work, amount of salary, type of assignment, promotion opportunities, relations between workers and others. Simultaneously, lecturers can be satisfied from the job side and can be dissatisfied from the other side.

Another research in similar context was also done at private universities in Bangladesh. The results showed that organizational culture; personal and professional growth opportunities, amount of salary, team cohesion, supportive policies, career security and growth; and working circumstance influence job satisfaction of lectures. From those factors, the three most influential are amount of salary, career security and growth; and working circumstance. Furthermore, the research stated that organizational commitment and creativity tend to espouse lecturers with high job satisfaction. Despite job dissatisfaction showed by some of lectures, the majority indicated a positive demeanor. Such positivity reflecting the optimism of an educator virtue.Apart from that, the study recommended that the authorities should consider the needs of providing better financial fitness and constructing a more supportive culture for the condition in which the faculty members are underpaid [55].

H6: Job satisfaction influences organizational commitment.

\subsection{Organizational Justice}

This is an elements concerning the fairness of treatments addressed to employees [24]. It is crucial, for both society and organizations, to be taken into consideration as reaction to injustice will disturb interactions and processes at work [25] for affective state of affairs, conjectures, and employees behavioral conducts towards the organization are most likely to be influenced by their perceptions related to organizational justice. Considering the importance, an implementation of equal basis and well-balanced treatment has to be the main focus of an organization in constructing ideal justice. The justice in question covers performance evaluation, career promotion, wellpaid salary, such dimensions will potentially promote employees' commitment and loyalty. In contrast, any form of injustice perceived will probably trigger unwanted outcomes, such as job dissatisfaction, bad performance, stress, cynicism, and skepticism towards the organization.

In psychological perspective, studies related to organizational justice were extensively conducted, particularly, to understand various human behavioral responses towards a management system in an organization. Such understanding is the uppermost concept needed to be consider. One of the research in this context was done in the Ilam city, at Sepah Bank (an Iranian Bank). It showed that the three major dimensions of organizational justice (interactional, distributive, and procedural justice) inflict the overall shift on employees' job satisfaction. Generally speaking, the study found that distributive justice acts as the most potent 
predictor with additional detail from which it was known that female employees gain more satisfaction in job rather than male employees [56].

There was also a study examined perceptions on organizational justice as a job satisfaction level predictor and organizational commitment. From which, it was known that distributive justice has a significant relation with job satisfaction, meanwhile, no significant relation was found between job satisfaction and procedural justice [57]. The findings also added the fact that organizational commitment is positively correlated to both procedural and distributive justice. Those who find themselves well-treated are potentially position the in a communal and mutual relation with the organization at which they work. Along with such condition, employees will simultaneously promote better trust, mutual control, commitment, and satisfaction [58]. The better employees' perceptions of the two dimensions of justice, the more satisfaction in job, commitment and loyalty they will have [23]. Based on these $s$, the hypotheses constructed in this study are:

H7: Organizational justice influences organizational commitment.

H8: Organizational justice influences job satisfaction.

H9: Organizational justice influences organizational commitment through job satisfaction.

\subsection{Organizational Commitment}

Organizational commitment is said to be the extent to which ones perceive themselves in their work at a particular organization [59], the perpetual intention to be well-connected to the organization [60], the psychological involvement of members in certain organizations [61]. Organizational commitment, simultaneously, acts as a psychological notion characterizing relationships between the organization and employees as well as implicate one's decisions to be loyal to a particular organization. Employees commitment in an organization is quantified based on three main affective commitment domains (one's intention to be affectively attached to, be identified as part of and be involved in an organization). Next, another type having function is Continuance commitment. It is an appraisal of costs borne by those who are not part of the organization, in case there no other options. There is also a kind called normative commitment which is the degree to which ones are psychologically bound to become members of an organization based on feelings such as loyalty, affection, warmth, belonging, pride, pleasure, happiness and others [14].

Organizational commitment also reflects the influence of suitability between individuals and organizations, although the results are not the same. Studies that examine this influence, find work experience that is in accordance with individual values and can meet individual needs and preferences influences organizational commitment [62]. Often, organizational commitment is portrayed as representing individuals invlovlement, attachment, and identification to anorganization [63]. Organizational commitment is recognized as important for the organization because it will determine organizational effectiveness, including previous research which found that job satisfaction affects organizational commitment, the more satisfied the employees are at work, the higher the organizational commitment [15]. Likewise, research on job satisfaction of employees in hospitality found that intrinsic and extrinsic satisfaction of a job influence commitment of employees in an organization significantly [64]. If employees are satisfied at work both intrinsically and extrinsically, this will potentially lead to robust boost on employees commitment in an organization. [65]. In specified terms, emotional or affective, and cognitive components are major construct in shaping satisfaction of a job. Therefore, individual appraisal of job satisfaction is the degree of how far work is able to lead to conclusive affective satisfaction or vice versa [18].

As what has been elucidated before that internal marketing influence organizational commitment a lot. However, there are other factors underlying the impact named organizational justice and job satisfaction. For organizational justice, it is one of the key elements impacting one's commitments in an organization and, at the same time, is an index of the effectiveness of an organization to run well in a proper condition. Referencing to the idea, it is prominent to consider more on raising both organizational justice and job satisfaction to be able to keep negativities away [20]. The description of ones perceptions of fairness they received from organizations and their behavioral reactions to such conduct are displayed in the way an organizational justice applied [22]. Furthermore, previous researches on this matter discovered that organizational commitment, job satisfaction, and organizational justice are inter-correlated. the justice predisposes commitment mediated by satisfaction at work; and, silmutaneously, the 
feeling of being satisfied greatly affect the development of organizational commitment. [27]. Based on these, these were the hypothesis formulated for this study:
H9: Organizational justice influences organizational commitment through job satisfaction.

\section{Research Model}

The following is the model of research proposed in this study:

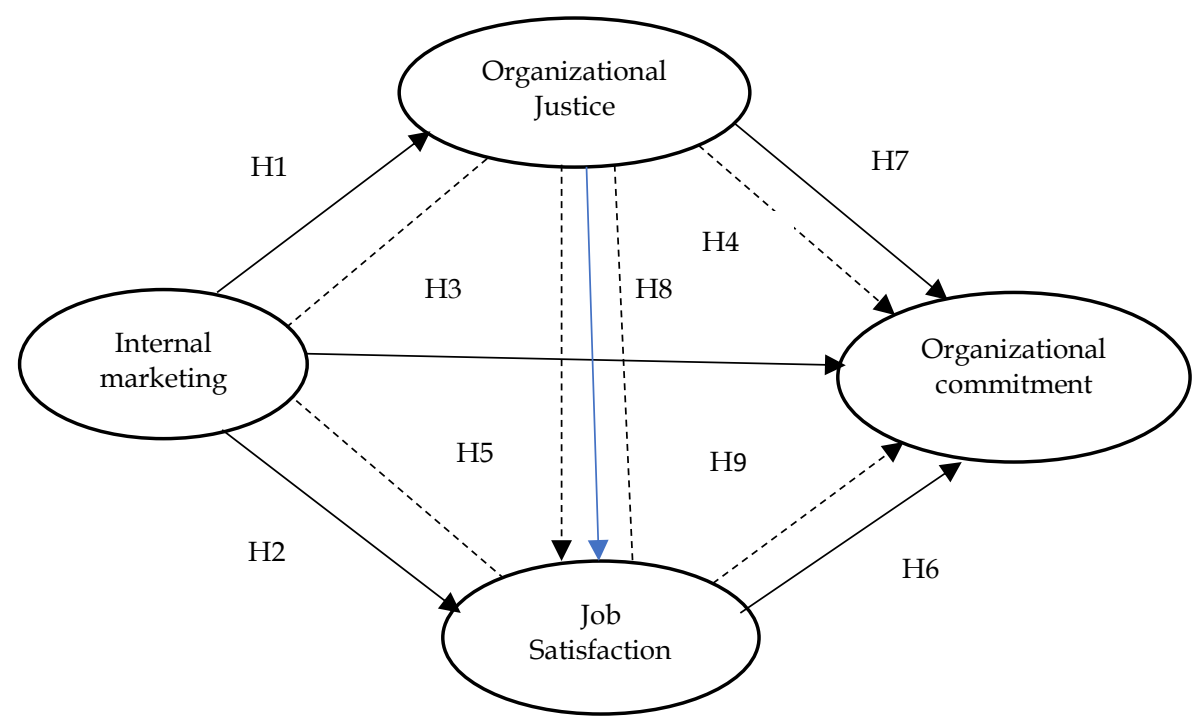

Figure 1: Research Model

\section{Research Method}

The study was designed in a quantitative approach of research using a deductive positivistic paradigm. The mean used in this study to collect primary data was survey. Practically, the research aims to test hypotheses as formulated before with the main object of influential correlation between internal marketing and organizational commitment via mediation of organizational justice and job satisfaction. Meanwhile, the target subjects were lectures working at private universities in Indonesia. This research used a survey method as the main instrument for data collection, primary data was collected through questionnaires.

The research was administered with all Faculty members of Economics and Business at a Private University in Indonesia as the population. The reason behind the selection of faculty members of Economics and Business study programs as the only population is that they tend to be similar in characters compared to using diverse ones. The sample were selected under purposive sampling technique in which they are chosen based on representative characters of the population.

The criteria in question were that the samples have to be lecturers teaching at institutions and study programs with, at least, B grade of accreditation. Apart from that, those who were selected as samples should hold National Lecturer Identification Number. Based on the consideration of limited costs, time and energy when a census was used, in this research the subjects were private universities under the Higher Education Service Institution, covering 14 regions.

The number of samples in this research were 200 samples as what has been Provided in a general reference of determining sample size [66]. Guidelines for sample measurement are specified from the basis number of anticipated indicators which is ranging from 5 to 10 times of those parameters [67]. The size of samples were decided under SEM (Structural Equation Model) which should be around 150-400 in total data [66], [67]. Therefore, the size of samples taken in this study in theoretically ideal. Finally, the data collected, then, were analyzed via a computer program named SmartPLS.

The process of data analysis, in this study, was under (SEM) Structural Equation Modeling. It is aims to model the interaction patterns; correlation between endogenous latent variables and exogenous latent variables; correlation error terms, measurement error, and non-linearity. Latent variables are formed by the relationship between the estimated indicators and are reflected in the research instrument. 
The calculation in the process of analysis was done with the help of a computer program named SmartPLS (Partial Least Square). This is a very powerful analysis program and, often, called "soft modeling" which negates OLS (Ordinary Least Square) regression assumptions. This model structure is composed of three relational analysis: 1) inner model (specifying the relations among latent variables/ structural model), 2) outer model (specifying relations between indictors and latent variables / model of measurement), 3) heft relations (specifying relations among predicted latent variables) [68].

\section{Research Results and Discussion \\ 5.1. Measurement Model Evaluation Analysis (Outer Model)}

In this analysis there are there criteria of reflective indicators used to gauge outer model. Those criteria are convergent validity (gauged from loading factor value), discriminant validity (gauged from cross loading value by looking at the value of Average Variance Extracted), and construct Reliability (gauged based on Cronbach's Alpha realibility and composite Reliability).

\subsection{Convergent Validity Testing and AVE Testing}

This type of test is related to a construct principality needing high correlation value. Such ideal will be there as there are high obtained values reflecting correlation between two distinguished measurement of instruments within a construct. the validity test was done under PLS by assessing reflective gauges predicated upon correlation between value of construct and values of item (loading factors). The scoring system of the matrix (communality) should be on \pm 30 (minimum degree), \pm 40 (better degree but not significant), or $>0.50$ (prominently influential). Therefore, the quality of a loading capability in interpreting a model is decided by the degree obtained. Meanwhile for convergent validity the outer loading values should be $>0.7$ with the value of AVE (average variance extracted) at $>0.5$ [69]. This type of construct validity is appraised by gauging estimated item score. The proper scale of loading value measurement to be said as legit should be at least 0.7 [70]. Figure 2 and table 1 display the results of the loading item values on the outer model as follows:

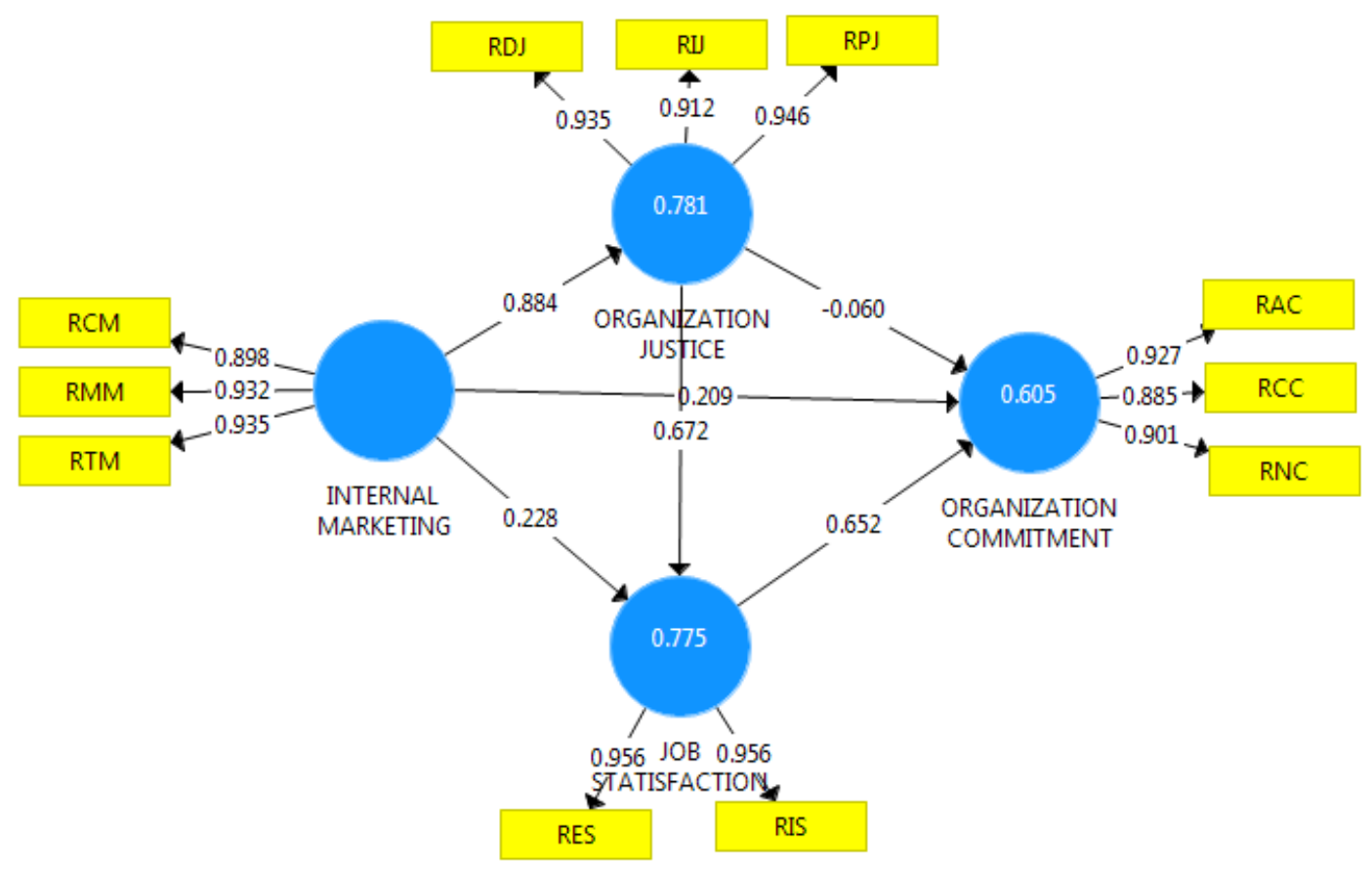

Figure 1: Outer Loading Test Results 
Table 1: Convergent Validity-Outer Loading Test Results

\begin{tabular}{|c|c|c|c|c|}
\hline & $\begin{array}{c}\text { Internal } \\
\text { Marketing }\end{array}$ & $\begin{array}{c}\text { Job } \\
\text { Statisfaction } \\
\end{array}$ & $\begin{array}{c}\text { Organizational } \\
\text { Commitment }\end{array}$ & $\begin{array}{c}\text { Organizational } \\
\text { Justice }\end{array}$ \\
\hline RAC & & & 0.927 & \\
\hline RCC & & & 0.885 & \\
\hline RCM & 0.898 & & & \\
\hline RDJ & & & & 0.935 \\
\hline RES & & 0.956 & & \\
\hline RIJ & & & & 0.912 \\
\hline RIS & & 0.956 & & \\
\hline RMM & 0.932 & & & \\
\hline RNC & & & 0.901 & \\
\hline RPJ & & & & 0.946 \\
\hline RTM & 0.935 & & & \\
\hline
\end{tabular}

Source: Primary Data Processed, 2020

In Table 1, it is known that all indicators on the internal marketing variable with a result range of 0.898- 0.935 , the job satisfaction variable had a value in the range of 0.956 , the organizational commitment variable was in the range $0.885-$
0.927 while the organizational justice variable was in the value range of $0.912-0.946$. The results above showed that all indicators or question items were valid, with an item value of outer loading $>$ 0.70 ; thus, it can be continued to the next analysis.

Table 2: AVE Testing

\begin{tabular}{|l|r|}
\hline & \multicolumn{1}{|c|}{ Average Variance Extracted (AVE) } \\
\hline Internal Marketing & 0.850 \\
\hline Job Statisfaction & 0.913 \\
\hline Organizational Commitment & 0.818 \\
\hline Organizational Justice & 0.867 \\
\hline
\end{tabular}

Source: Primary Data Processed, 2020

Table 2 shows that the whole items included in the construct are relatively valid for each value of AVE and outer loading resulted in the scale of $>$ 0.70 ; thus, further analysis can be carried out.

\subsection{Reliability Testing (Composite Reliability)}

The construct reliability can be gauged by apprasing the value of composite reliability as it reflects the actual realibility value [71]. The ideal value for a construct to be considered as reliable should be $>0.7$, even though, the value below (not $<0.6)$ is still admissible. The results of reliability test in this study are displayed in Table.2:

Table 2: Reliability Test Results

\begin{tabular}{|l|r|}
\hline & Composite Reliability \\
\hline Internal Marketing & 0.944 \\
\hline Job Statisfaction & 0.955 \\
\hline Organizational Commitment & 0.931 \\
\hline Organizational Justice & 0.951 \\
\hline
\end{tabular}

Source: Primary Data Processed, 2020

The data displayed in table 2 showed that, for all items, the value of composite reliability reached were $>0.70$. this means that the whole construct is considered reliable. The display also shows the 
instrument stability and consistency were considerably high. In other words, it can, safely, be said all requirements for reliability were met .

\subsection{Structural Model Evaluation Analysis (Inner Model)}

The analysis was carried out to specified relationship pattern among variables included in the construct as what has been hypothesized. The evaluation was done by identifying R-square values for dependent notion and by running the T-test to examined significance in the pattern of relation among variables in the construct. The analysis first began by identifying R-square values for each dependent variable whose exegesis was reflected in regression. The alteration in $\mathrm{R}$-square values is particularly functioned to measure the effect of a specified latent independent variables on latent dependent variable as well as examined if it is substantively effective

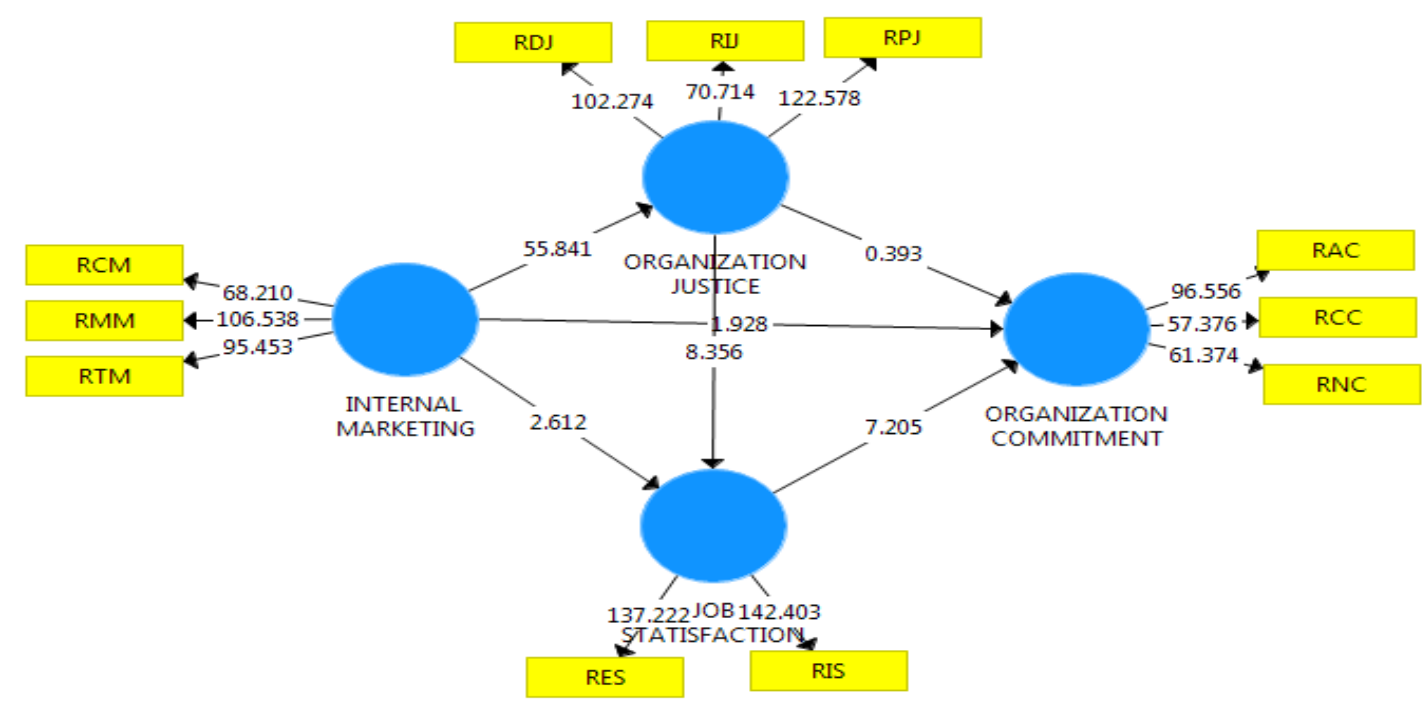

Figure 2: Evaluation of the Structural Model (Inner Model)

\subsection{Coefficient Value and Hypothesis Test Results (Direct Effects)}

The coefficient value with the estimated value is used to examine he relationship directions among variables covered. Display of such directions are shown in Table as follow:

Table 3: Hypothesis Test Results (Direct Effects)

\begin{tabular}{|l|r|r|r|r|c|}
\hline & $\begin{array}{c}\text { Original } \\
\text { Sample } \\
(\mathbf{O})\end{array}$ & $\begin{array}{c}\text { Sample } \\
\text { Mean } \\
(\mathbf{M})\end{array}$ & $\begin{array}{c}\text { Standard } \\
\text { Deviation } \\
(\text { STDEV) }\end{array}$ & $\begin{array}{c}\text { T Statistics } \\
(\mid \mathbf{O} / \text { STDEV })\end{array}$ & \multicolumn{1}{c|}{$\begin{array}{c}\text { P } \\
\text { Values }\end{array}$} \\
\hline $\begin{array}{l}\text { Internal Marketing -> Job } \\
\text { Statisfaction }\end{array}$ & 0.228 & 0.230 & 0.087 & 2.612 & 0.009 \\
\hline $\begin{array}{l}\text { Internal Marketing -> } \\
\text { Organizational Commitment }\end{array}$ & 0.209 & 0.213 & 0.108 & 1.928 & 0.054 \\
\hline $\begin{array}{l}\text { Internal Marketing -> } \\
\text { Organizational Justice }\end{array}$ & 0.884 & 0.885 & 0.016 & 55.841 & 0.000 \\
\hline $\begin{array}{l}\text { Job Statisfaction -> } \\
\text { Organizational Commitment }\end{array}$ & 0.652 & 0.658 & 0.090 & 7.205 & 0.000 \\
\hline $\begin{array}{l}\text { Organizational Justice -> Job } \\
\text { Statisfaction }\end{array}$ & 0.672 & 0.671 & 0.080 & 8.356 & 0.000 \\
\hline $\begin{array}{l}\text { Organizational Justice -> } \\
\text { Organizational Commitment }\end{array}$ & -0.060 & -0.070 & 0.153 & 0.393 & 0.694 \\
\hline
\end{tabular}

Source: Primary Data Processed, 2020 
From the data display in tabel 3 , it is obvious that the results of the $\mathrm{T}$ test display the effect of internal marketing on job satisfaction, organizational commitment, and organizational justice. similarly, the data is also used in determining the extent of job satisfaction effect on organizational commitment as well as organizational justice effect on job satisfaction and commitment for organization. In this research, there were 6 hypotheses to test the direct effect. There was a significant effect if the T-statistic value was $>1.96$ at the $5 \%$ significance level.

\subsection{Coefficient Value and Hypothesis Test Results (Indirect Effects)}

The indirect effects test results of the hypothesis are displayed as follow:

Table 4: Hypothesis Test Results (Indirect Effects)

\begin{tabular}{|c|c|c|c|c|c|}
\hline & $\begin{array}{l}\text { Original } \\
\text { Sample } \\
\text { (O) }\end{array}$ & $\begin{array}{l}\text { Sample } \\
\text { Mean } \\
\text { (M) }\end{array}$ & $\begin{array}{l}\text { Standard } \\
\text { Deviation } \\
\text { (STDEV) }\end{array}$ & $\begin{array}{l}\text { T Statistics } \\
\text { (|O/STDEV|) }\end{array}$ & $\begin{array}{c}\mathbf{P} \\
\text { Values }\end{array}$ \\
\hline $\begin{array}{l}\text { Internal Marketing -> } \\
\text { Organizational Justice -> Job } \\
\text { Statisfaction }\end{array}$ & 0.594 & 0.594 & 0.074 & 8.026 & 0.000 \\
\hline $\begin{array}{l}\text { Internal Marketing -> } \\
\text { Organizational Justice } \\
\rightarrow \text { Organizational Commitment }\end{array}$ & 0.483 & 0.480 & 0.107 & 4.492 & 0.000 \\
\hline $\begin{array}{l}\text { Organizational Justice ->Job } \\
\text { Satisfaction } \rightarrow \text { Organizational } \\
\text { Commitment }\end{array}$ & 0.438 & 0.444 & 0.094 & 4.681 & 0.000 \\
\hline
\end{tabular}

Source: Primary Data Processed, 2020

\subsection{HypothesisTesting}

Based on Tables 3 and 4 above, the results of hypothesis testing with Smart Partial Least Square 25 for direct and indirect effects can be explained as follows:

\subsubsection{Hypothesis 1: Internal Marketing} influences Organizational Justice.

The coefficient value of effect of internal marketing in influencing organizational justice was at 55.841 with $p$ value of $0.000<0.005$. the tes was done with PLS approach. Such value is considered as positive, hence, it can be concluded that the influence between those variables was unidirectional, meaning that the better the internal marketing, the better the organizational justice.

Based on the the t-test result, it known that the coefficient value is statistically high $(55,841)$ as $\mathrm{t}$-statistic value was greater than the $\mathrm{t}$-table of 2.00 , the hypothesis that stated "internal marketing influences organizational justice" was accepted.

\subsubsection{Hypothesis 2: Internal Marketing influences Job Satisfaction. \\ The coefficient value of effect of internal} marketing in influencing organizational justice was at 55.841 with $\mathrm{p}$ value of $0.000<0.005$. the tes was done with PLS approach. Such value is considered as positive, hence, it can be concluded that the influence between those variables was unidirectional, meaning that the better the internal marketing, the better the organizational justice.

Based on the the t-test result, it known that the coefficient value is statistically high $(55,841)$ as $\mathrm{t}$-statistic value was greater than the $\mathrm{t}$-table of 2.00 , the hypothesis that stated "internal marketing influences organizational justice" was accepted.

\subsubsection{Hypothesis 3: Internal Marketing influences Organizational Commitment. \\ The coefficient value of effect of internal} marketing in influencing organizational commitment with the value of 1.928 (p value $0.954>0.005)$. such result emerged as t-statistic value was less than the t-table (2.00), hence, the hypothesis which stated "Internal marketing influences organizational commitment" was rejected.

\subsubsection{Hypothesis 4: Internal Marketing influences Organizational Commitment mediated by Organizational Justice. \\ The test results with the PLS approach} resulted in the coefficient value of internal marketing influence on organizational commitment mediated by organizational justice with the value of 4.492 with significance value of $0.000<0.005$. The result of the coefficient value was positive, hence, it is safe to say that the influence between those two was unidirectional, meaning that the better the 
internal marketing, the better the organizational commitment.

Such result emerged as t-statistic value gained wa more than t-table (2.00), therefore, the hypothesis which stated " job satisfaction acts as a mediator for Internal marketing in influencing organizational commitment " was accepted.

\subsubsection{Hypothesis 5: Internal Marketing influences Job Satisfaction mediated by Organizational Justice.}

The test results with the PLS approach resulted in the coefficient of relational value between organizational justice as a mediator for internal marketing in influencing job satisfaction with the value of 8.026 ( $\mathrm{p}$ value $0.000<0.005$ ). The result of the coefficient value was positive, it can be concluded that the influence between the two was unidirectional, meaning that the higher quality of internal marketing, the more satisfied employees in their job.

The test resulted in such value as the value of t-statistic gained was more than the t-table (2.00), thus, the hypothesis stated that "Internal marketing influences job satisfaction mediated by organizational justice" was proven.

\subsubsection{Hypothesis 6: Job Satisfaction influences Organizational Commitment.}

The test results showed that job satisfaction influence organizational commitment at a value of 7.205 ( $p$ value $0.000<0.005$ ). as the coefficient value was positive, it can be concluded that the influence between the two was unidirectional. It means that a high organizational commitment is more likely to be achieved if job satisfaction content is high.

Such value was gained in the test result for t-statistic value was more than the t-table (2.00), therefore, the hypothesis stated "job satisfaction influences organization commitment" was accepted.

\subsubsection{Hypothesis 7: Organizational Justice influences Organizational Commitment.}

The coefficient value of 0.393 ( $p$ value $0.694>0.005)$ was resulted in the test with the PLS approach produced, related to the examination of organizational justice influence on organizational commitment. Based on the results the value of
1.928 was gained as the result of smaller t-statistic value compared to t-table value (2.00), thus, the hypothesis which stated "Organizational justice influences organizational commitment" was rejected

\subsubsection{Hypothesis 8: Organizational Justice affects Job Satisfaction.}

The coefficient value of 8.356 ( $p$ value $0.000<0.005)$ was resulted in the test with PLS approach concerning organizational justice influence on job satisfaction. The result of the coefficient value was positive; it can be concluded that the influence between the two was unidirectional. It means that the higher the organizational justice, the more satisfied the employees will be.

The value gained in the test was the result of smaller value in t-statistic compared to t-table (2.00), hence, the hypothesis which stated that "Organizational justice influences job satisfaction" was accepted.

\subsubsection{Hypothesis 9: Organizational Justice influences Organizational Commitment mediated by Job Satisfaction.}

The coefficient value of 4.681 ( $p$ value $0.000<0.005$ ) was resulted in the test with the PLS approach concerning relational value between job satisfaction as a mediatr for organizational justice in its influence on organizational commitment. The result of the coefficient value was positive, it can be concluded that the influence between the two was unidirectional, meaning that the higher the quality of organizational justice, the stroger the organizational commitment will be.

Such value gained in the result was due to bigger tstatistic value compared to the value of t-table (2.00), thus, the hypothesis which stated "organizational justice influences organizational commitment mediated by job satisfaction" was accepted.

\subsection{Inner Model Analysis (Goodness of fit model)}

By identifying the value of R-square as goodness of fit model, this test was set to examine the structural model used. Such value represents the prediction of relations among laten variables as mentioned in hypotheses. The process of analysis was done with the help of PLS. In procedures, The analysis first began by identifying $\mathrm{R}$-square values 
for each dependent variable whose exegesis was reflected in regression. The alteration in R-square values is particularly functioned to measure the effect of a specified latent independent variables on latent dependent variable as well as examined if it is substantively effective. Bigger R-square value means better proportion. Below is the display of the result of Inner model test reflected in Table 5.

Table 5: Inner Model Results (Goodness of fit model)

\begin{tabular}{|c|c|c|c|c|c|}
\hline & $\begin{array}{c}\text { Original } \\
\text { Sample } \\
(\mathbf{O})\end{array}$ & $\begin{array}{c}\text { Sample } \\
\text { Mean } \\
(\mathbf{M})\end{array}$ & $\begin{array}{c}\text { Standard } \\
\text { Deviation } \\
(\text { STDEV })\end{array}$ & $\begin{array}{c}\text { T Statistics } \\
(\mid \mathbf{O} / \text { STDEV|) }\end{array}$ & $\begin{array}{c}\mathbf{P} \\
\text { Values }\end{array}$ \\
\hline Job Statisfaction & 0.775 & 0.778 & 0.035 & 22.156 & 0.000 \\
\hline Organizational Commitment & 0.605 & 0.613 & 0.056 & 10.735 & 0.000 \\
\hline Organizational Justice & 0.781 & 0.783 & 0.028 & 28.010 & 0.000 \\
\hline
\end{tabular}

Source: Primary Data Processed, 2020

The data shown above indicates that $\mathrm{R}$-square value for job satisfaction was at 0.775 . This means that the job satisfaction explained by the internal marketing variable was $77.5 \%$. The R-square value for the organizational commitment variable was 0.605 , which means that the job satisfaction, internal marketing, adn organizational justice modify organizational commitment by $60.5 \%$. Meanwhile for, organizational justice, the value gained was at 0.781 . This means that organizational justice was explained by the internal marketing variable of $78.1 \%$.

\section{Discussion}

\subsection{Internal Marketing influences Organizational Justice}

Based on the results of the analysis it is known that internal marketing influenced organizational justice which was shown from the $T$ statistical value of the results of the t-statistic test of 55.841, because the $t$-statistic value was greater than the t-table 2.00, the hypothesis that stated "internal marketing influences organizational justice" was proven. This means that organizations that apply good internal marketing practices will be able to apply proper fainess in the organization.

This study has in line findings with previous research which was administered in Turkey, at Kayseri shopping district, targeting 157 employees of service-related company. The findings contained in the study showed that internal marketing practices carried out by service companies to employees have an influence on organizational justice. This research recommends that organizations apply organizational justice that is grown from the existence of good internal marketing practices in the organization [72]. For individuals and communities, perceptions of organizational justice are important because it will influence their opinions, feelings, and behavior towards the organization [19]. The perception of justice applies universally, including to private university lecturers in Indonesia.

\subsection{Internal Marketing influences Job Satisfaction}

The data analysis results, in this study, indicate that that internal marketing influenced job satisfaction as shown by the T-value of the statistical t-test results of 2.612, as the value gained form statistic calculation was more than than the value of t-table (2.00), thus, the hypothesis stated that "internal marketing influences job satisfaction" was proven. This means that organizations that apply good internal marketing practices will increase employee job satisfaction.

In line with the findings in this study, previous researches also suggest that internal marketing have an influence on job satisfaction. One of which was done in the organizational context on cultural congruence (organizational and personal) as a moderator between internal marketing and job satisfaction in hospitality-related workplace (tourism) with the target subjects consisting employees born either in Australia or Taiwan. Another example was done in Australia targeting samples of total 458 employees working in tourismrelated business. It was proven empirically that more qualified internal marketing praxis leads to job satisfaction increase [12]. similarly, there was also a study done in Bangladeshi insurance companies with the purpose of examining internal marketing practices influence on frontline employees' perceptions. In the research, it was found that the internal marketing program was assessed positively by frontline employees (FLE) resulting in employees who were satisfied with their 
jobs, this job satisfaction resulted in better employee performance [71].

\subsection{Internal Marketing influences Organizational Commitment}

The data analysis results contained in this study proved that the practice of internal marketing did not influence organizational commitment as indicated by the statistical $T$ value of the statistical t-test of 1.928 , because the t-statistic value was smaller than the t-table 2.00, the hypothesis stating that "job satisfaction is influenced by internal marketing " was rejected.

The findings of this research contradict previous studies proving that internal marketing influences organizational commitment [6]. Likewise, another research also stated that internal marketing is the principal approach in achieving ideal employees commitment in an organization [74]. In the same view, the other studies also suggested that the increase of organizational commitment and job satisfaction are the impact of internal marketing influence [33], [75], [76].

This study failed to find the direct connection between the escalation of organizational commitment as the impact of internal marketing practice. In fact, the results showed that Internal marketing did not directly affect organizational commitment, but has to be mediated by organizational justice before the specified influence applied [72].

In line with this study, it was found in a research that only if it is in the form of procedural, interactional distributive justice, organizational justice [56] will influence job satisfaction significantly, which in turn it will impact the escalation of organizational commitment. Referencing to researches done on this matter, including this study, it is known that there are two different kind of findings (those who proved that internal marketing and organizational commitment have a direct influential relation and who didn't/failed to prove)

\subsection{Internal Marketing influences Organizational Commitment mediated by Organizational Justice}

Under the PLS approach, the data analysis results in this research displayed the coefficient value regarding influential relation between organizational commitment and internal marketing praxis at 4.492 ( $\mathrm{p}$ value $0.000<0.005$ ). The result of the coefficient value was positive, hence, it can be concluded that the influence between the two was unidirectional, meaning that the higher the quality of internal marketing pratices implemented, the more organizational commitment will be extended.

The cause behind the value gain was the greater number of t-statistic value compared to the value of t-table( 2.00 ), thus, the hypothesis which stated "Internal marketing, mediated byorganizational justice, influences organizational commitment significantly" was proven to be true.

Such result was accord what previous studies showed, that organizational commitment is influenced by internal marketing through the mediation from organizational justice. Specifically, the study found that lecturers with well-treated condition will promote more commitment. This condition is the impact of perceived view considering internal marketing practice as shaping justice (procedural, interactional, and distributive) in the organization and, in turn, it will promote the escalation of organizational commitment [6] [74].

\subsection{Job Satisfaction influences Organizational Commitment}

Being tested under PLS approach, the data analysis resulted in the coefficient value of influential relation betweem job satisfaction and organizational commitment at 7.205 ( $p$ value 0.000 $<0.005$ ). The result of the coefficient value was positive, it can be concluded that the influence between the two was unidirectional, meaning that organizational commitment improvement is triggered by higher job satisfaction.

The results gained due to greater value of $t-$ statistic compared to t-table (2.00). Based on this, the hypothesis stated "job satisfaction influences organizational commitment" was proven.

In line with this study, the previous one done in higher institutions found job satisfaction influence on organizational commitment. The satisfaction of Lecturers in there is said to be correlated to a bunch of complexity named demographic character, type of work, salary, type of assignment, promotion opportunities, relations between workers and other factors. Simultaneously, lecturers can be satisfied from the job side and can be dissatisfied from the other side [75].

Similarly, another study done in Bangladesh, set in private higher educational institutions, proved that compensation, career security, opportunities for personal growth, cohesive team, career-related growth, working circumstance, working culture and policies in the organization bring prominent influences on job satisfaction. However, among those dimensions; compensation, career security 
and working circumstance hold highest influence. In a nut shell, lecturers with high satisfaction are more likely to be committed and creative in their profession [56].

\subsection{Organizational Justice influences Organizational Commitment}

The coefficient value of influential correlation between organizational justice and organizational commitment was found at the value of 0.393 (p value $0.694>0.005$ ). This condition happened due smaller value of t-statistic value compared to t-table (2.00), that is why, the hypothesis stated that "Organizational justice influences organizational commitment" was not proven.

Similar to this research, the previous one done in Canada taking 213 teachers as samples found that there was no influential correlation between organizational justice and organizational commitment [78].

\subsection{Organizational Justice influences Job Satisfaction}

The data analysis result showd the coefficient of influential connection between organizational justice and job satisfaction at the value of 8.356 ( $p$ value $0.000<0.005$ ). The result of the coefficient value was positive, it can be concluded that the influence between the two was unidirectional, meaning that notable organizational justice impleentation inflicted job satisfaction promotion.

Such condition was occured for bigger number of t-statistic value compared to t-table (2.00), thus, the hypothesis stated that "job satisfaction increase is impacted by the influence of the practice of organizational justice influences " was accepted.

Likewise, previous study also found that employees fairly treated are more likely to be content with their job and willing to well behaved as well as being productive and creative [79], [80]. Additionally, another similar research proved that the practice of organizational justice is positively related to the development of job satisfaction [21].

\subsection{Organizational Justice influences Organizational Commitment mediated by Job Satisfaction}

Set with the help of PLS approach, this study found the coefficient of influential connectivity between organizational justice and organizational commitment, via job satisfaction mediation, at thevalue of 4.681 ( $p$ value $0.000<0.005$ ). The result of the coefficient value was positive, thus, it is safely deduced that the influential relation between the two was unidirectional, meaning that organizational justice maintain in a robust manner helps the organizational commitment growth.

Such situation occurred for the greater number of $\mathrm{t}$-statistic value compared to $\mathrm{t}$-table (2.00), hence, it is safe to say that hypothesis stated that "by the mediation of job satisfaction, organizational commitment is affected by organizational justice" was accepted.

Contextually similar, a number of previous studies discovered that proper income distribution leads to job contentment, and, in turn, it allows organizational commitment to sprout [81]. Another linear result was also found, proving that commitment is highly influenced by organizational justice [19], [82].

\section{Conclusion, Contribution Research \\ Research and Future} 7.1. Conclusion

This research examined the influence of internal marketing on organizational commitment with job satisfaction and organizational justice as mediating variables on private universities in Indonesia. Based on the research results, the following conclusions were obtained:

1. The results of convergent validity testing as seen from the loading factor value for all indicators on the internal marketing, job satisfaction, organizational commitment and organizational justice variables showed that all indicators or question items were valid, with an outer loading value of $>0.7$.

2. The results of reliability testing conducted by looking at the composite reliability value show that all constructs have a value $>0.7$. Based on this value, it can be concluded that the instrument reliability was met.

3. The result of research hypothesis testing:
a. Internal marketing influenced organizational justice.
b. Internal marketing influenced job satisfaction.
c. Internal marketing did not influence organizational commitment.
d. Internal marketing influenced organizational commitment mediated by job satisfaction.
e. Internal marketing influenced job satisfaction mediated by organizational justice.
f. Job satisfaction influenced organizational commitment.


g. Organizational justice did not influence organizational commitment.

h. Organizational justice influenced job satisfaction.

i. Organizational justice influenced organizational commitment mediated by job satisfaction.

\subsection{Research Contribution}

This research provides the following theoretical and practical contributions:

\subsubsection{Theoretical Contribution}

This research consisted of 4 constructs, namely internal marketing, organizational commitment, organizational justice and job satisfaction. The construct had been tested for validity and reliability and showed that this research met the requirements for validity and reliability; thus, this research can be replicated for future studies.

a. Most of the hypotheses proposed in this research were proven or in line with the findings of previous studies, except for the third hypothesis, namely internal marketing did not influence organizational commitment. Internal marketing does not directly affect organizational commitment, this was not in line with the results of previous studies which showed that Internal marketing influenced organizational commitment [6], as well as the results of other studies which showed job satisfaction and organizational commitment can be increased by internal marketing [33], [75], [76]. Internal marketing must go through organizational justice first then organizational commitment, this can be explained that in order to foster the organizational commitment of lecturers, private high institutions need to act fairly first, the values of justice felt by lecturers will grow organizational commitment. This finding was in line with the research which showed that organizational justice mediated between internal marketing on organizational commitment [74]. Lecturers perceived that internal marketing practiced by institutions aims to build organizational justice, for distributive, procedural and interactional, the justice that is felt by lecturers ultimately influenced organizational commitment.

b. The seventh hypothesis which stated that organizational justice influences organizational commitment was not proven. The results of this research indicated that when the influence of organizational justice directly on organizational commitment was tested, it was not proven, but when tested using mediation job satisfaction, it was proven. This showed that to foster organizational commitment, private higher education institutions need to first create fair treatment of lecturers, for distributive justice (salary, reward, job appraisal, equal opportunity for self-development), procedural justice and interactional justice. This organizational justice will be responded to in the form of job satisfaction by lecturers, lecturers who are satisfied with their work will eventually foster organizational commitment to their institutions.

\subsubsection{Practical Contribution}

Practical contributions or managerial implications are practical uses of research results. The practical implications of this research are as follows:

a. Primarily, this study contributes to be practical reference for authorities in private universities in order to allow organizational commitment sprout among lecturers. it is important for universities to practice internal marketing, build job satisfaction and create organizational justice. The increasing organizational commitment of lecturers will have an impact on good service to students, students who are satisfied with the service of lecturers will have a good impact on private university, for example with a positive eWOM.

b. For marketing practitioners, it was found that these variables influenced the organizational commitment including good internal marketing practices in organizations, employee job satisfaction and organizational justice practices. Thus, marketing practitioners need to understand aspects within the organization when satisfying their external customers. In the context of the private high education organization, managers can use the constructs built in this research to foster the organizational commitment of the lecturers.

\subsection{Research Limitations and Future Research}

Although this research was conducted by following scientific research guidelines using the Structural Equation Model (SEM) with the Partial Least Square (PLS) program, there are still some limitations that can be an opportunity for further research. The limitations are as follows:

1. This research did not use demographic control variables, such as age, gender, education; thus, demographic bias may arise.

2. The sample of lecturers was not differentiated between lecturers appointed by the Private Higher Education Foundation and state 
lecturers who assisted PTS. This condition can lead to organizational commitment bias due to different employment statuses.

3. Lecturers who were the research sample were also not differentiated whether the lecturers who were currently in office, lecturers who had served or lecturers who had never served at all. This condition also allows the emergence of organizational commitment bias because of the intensity of its involvement in organizational management.

\section{References}

[1] H. S. Becker, "Notes on the Concept of Commitment," Am. Sociol., p. 9, 1960.

[2] A. Etzioni, Complex Organizations: A Sociological Reader. New York: Holt, 1961.

[3] R. M. Kanter, "Commitment and Social Organization: A Study of Commitment Mechanisms in Utopian Communities," Am. Sociol. Rev., vol. 33, no. 4, p. 499, Aug. 1968, doi: $10.2307 / 2092438$.

[4] R. A. Stebbins, "On Misunderstanding The Concept Of Commitment: A Theoretical Clarification," Soc. Forces, vol. 48, pp. 526529, 1970.

[5] L. W. Porter, R. M. Steers, R. T. Mowday, and P. V. Boulian, "Organizational Commitment, Job Satisfaction, and Turnover Among Psychiatric Technicians," J. Appl. Psychol., vol. 59, no. 5, p. 7, 1974.

[6] B. R. Barnes and D. S. Morris, "Revising Quality Awareness Through Internal Marketing: An Exploratory Research Among French And English Medium-Sized Enterprises," Total Qual. Manag., vol. 11, pp. 473-483, 2000.

[7] D. Helman and A. Payne, "Internal Marketing Myth Versus Reality in Payne, A. (Ed), Advances in Relationship Marketing," The Cranfield Management Series and Kogan Page, London, 1995.

[8] A. Sargeant and S. Asif, "The strategic application of internal marketing - an investigation of UK banking," Int. J. Bank Mark., vol. 16, no. 2, pp. 66-79, Apr. 1998, doi: $10.1108 / 02652329810206716$.

[9] M. Rafiq and P. K. Ahmed, "The scope of internal marketing: Defining the boundary between marketing and human resource management," J. Mark. Manag., vol. 9, no. 3, pp. 219-232, Jul. 1993, doi: 10.1080/0267257X.1993.9964234.
[10] A. Caruana and P. Calleya, "The effect of internal marketing on organisational commitment among retail bank managers," Int. J. Bank Mark., vol. 16, no. 3, pp. 108-116, Jun. 1998, doi: 10.1108/02652329810213510.

[11] C. Boshoff and M. Tait, "Quality perceptions in the financial services sector: The potential impact of internal marketing," Int. J. Serv. Ind. Manag., vol. 7, no. 5, pp. 5-31, Dec. 1996, doi: 10.1108/09564239610149939.

[12] Y.-T. Huang and S. Rundle-Thiele, "The moderating effect of cultural congruence on the internal marketing practice and employee satisfaction relationship: An empirical examination of Australian and Taiwanese born tourism employees," Tour. Manag., vol. 42, pp. 196-206, Jun. 2014, doi: 10.1016/j.tourman.2013.12.005.

[13] H. S. Bansal, M. B. Mendelson, and B. Sharma, "The Impact of Internal Marketing Activities on External Marketing Outcomes," J. Qual. Manag., vol. 6, no. 1, pp. 61-76, Oct. 2001, doi: 10.1016/S1084-8568(01)00029-3.

[14] N. J. Allen and J. P. Meyer, "The measurement and antecedents of affective, continuance and normative commitment to the organization," J. Occup. Psychol., vol. 63, no. 1, pp. 1-18, Mar. 1990, doi: 10.1111/j.2044-8325.1990.tb00506.x.

[15] H. K. S. Laschinger and J. Finnegan, "Using Empowerment To Builts Trust And Respect In The Workplace: A Strategy For Addressing The Nursing Shortage," Nurs. Econ., vol. 23, no. 1, p. $6,2005$.

[16] M. R. Testa, "Organizational commitment, job satisfaction, and effort in the service environment," J. Psychol. Interdiscip. Appl., vol. 135, no. 2, pp. 226-236, 2001, doi: $10.1080 / 00223980109603693$.

[17] E. A. Locke, The Nature and Causes of Job Satisfaction Handbook of Industrial and Organizational Psychology. Rand Mc Nally College: Publishing Company, 1976.

[18] B. Coomber and L. Barriball, "Impact of Job Satisfaction Components on Intent to Leave and Turnover for Hospital-based Nurses: A Review of the Research Literature," Int. J. Nurs. Stud., vol. 44, no. 2, pp. 297-314, Feb. 2007, doi: 10.1016/j.ijnurstu.2006.02.004.

[19] W. D. Hawkins and D. J. Parks, "Predictors of Affective Organizational Commitment Among High School Principals Doctor of Education in Educational Administration," 
Doctoral Thesis, Faculty of Virginia Institute and State Univercity, Virginia, 1998.

[20] B. Yiğitol and Ö. Balaban, "Relationship between Organizational Justice and Employee Satisfaction : Evaluation of Human Resources Functions," pp. 1-9, 2018.

[21] H. A. Al-Zu'bi, "A Study of Relationship between Organizational Justice and Job Satisfaction," Int. J. Bus. Manag., vol. 5, no. 12, 2010, doi: 10.5539/ijbm.v5n12p102.

[22] C. Fernandes and R. Awamleh, "Impact of Organisational Justice in An Expatriate Work Environment," Manag. Res. News, no. 29, pp. 701-712, 2006.

[23] C. K. Fatt, E. W. S. Khin, and T. N. Heng, "The Impact of Organizational Justice on Employee's Job Satisfaction: The Malaysian Companies Perspectives," p. 9, 2010.

[24] R. H. Moorman, "Relationship Between Organizational Justice dnd Organizational Citizenship Behaviors: Do Fairness Perceptions Influence Employee Citizenship," J. Appl. Psychol., no. 76, pp. 845-855, 1991.

[25] M. Alsalem and A. Alhaini, "Relationship between Organizational Justice and Employees Performance," Aledari, vol. 108, pp. 97-110, 2007.

[26] R. H. Moorman, B. P. Niehoff, and D. W. Organ, "Treating Employees Fairly and Organizational Citizenship Behavior: Sorting The Effects of Job Satisfaction, Organizational Commitment, and Procedural Justice," Empl. Responsib. Rights J., vol. 6, pp. 209-225, 1998.

[27] M. D. Fulford, "That's Not Fair!: The Test of a Model of Organizational Justice, Job Satisfaction, and Organizational Commitment Among Hotel Employees," J. Hum. Resour. Hosp. Tour., vol. 4, no. 1, pp. 73-84, Sep. 2005, doi: 10.1300/J171v04n01 06.

[28] P. K. Ahmed, M. Rafiq, and N. M. Saad, "Internal marketing and the mediating role of organisational competencies," Eur. J. Mark., vol. 37, no. 9, pp. 1221-1241, Oct. 2003, doi: 10.1108/03090560310486960.

[29] L. L. Berry, J. S. Hensel, and M. C. Burke, "Improving Retailer Capability for Effective Consumerism Response," J. Retail., vol. 52, no. 3, pp. 3-14, 1976.

[30] M. Abzari, H. Ghorbani, and F. Alsadat Madani, "The Effect of Internal Marketing on Organizational Commitment from MarketOrientation Viewpoint in Hotel Industry in
Iran," Int. J. Mark. Stud., vol. 3, no. 1, p. p147, Jan. 2011, doi: 10.5539/ijms.v3n1p147.

[31] P. K. Ahmed and M. Rafiq, "Internal marketing issues and challenges," Eur. J. Mark., vol. 37, no. 9, pp. 1177-1186, Oct. 2003, doi: 10.1108/03090560310498813.

[32] D. B. Arnett, S. D. German, and S. D. Hunt, "The Identity Salience Model of Relationship Marketing Success: The Case of Nonprofit Marketing," J. Mark., vol. 67, no. 2, pp. 89105, 2003.

[33] M. Rafiq and P. K. Ahmed, "Advances in the internal marketing concept: definition, synthesis and extension," J. Serv. Mark., vol. 14, no. 6, pp. 449-462, Nov. 2000, doi: $10.1108 / 08876040010347589$.

[34] L. L. Berry and A. Parasuraman, Marketing Service. New York: The Free Press, 1991.

[35] C. Gronroos, "A Service Quality Model and It's Marketing Implications," Eur. J. Mark., vol. 18, no. 4, pp. 36-44, 1982.

[36] L. Berry, "The Employee as Customer," $J$. Retail. Bank., vol. 3, pp. 25-28, 1981.

[37] C. Gronroos, "Internal Marketing-Theory and Pratice," Am. Assoc. Serv. Conf. Proceeding, pp. 41-47, 1985.

[38] D. Ballantyne, "A Relationship-Mediated Theory of Internal Marketing," Eur. J. Mark., vol. 37, no. 9, pp. 1242-1260, Oct. 2003, doi: 10.1108/03090560310486979.

[39] I. N. Lings, "Internal market orientation," $J$. Bus. Res., vol. 57, no. 4, pp. 405-413, Apr. 2004, doi: 10.1016/S0148-2963(02)00274-6.

[40] R. J. Varey and B. R. Lewis, "A broadened conception of internal marketing," Eur. J. Mark., vol. 33, no. 9/10, pp. 926-944, Oct. 1999, doi: 10.1108/03090569910285869.

[41] W. R. George, "Internal Marketing and Organizational Behavior a Partnership in Developing Customer-Consenious Employes at 207 Every Level," J. Bus. Res., vol. 20, pp. 63-70, 1990.

[42] M. Glassman and B. McAfee, "Integrating The Personnel And Marketing Functions: The Challenge Of The 1990s," Bus. Horiz., vol. 35, no. 3, pp. 52-59, 1992.

[43] Flippo, Personal Manajemen, 6th ed. USA: Mc Graw Hill Inc, 1986.

[44] N. Piercy and N. Morgan, "Internal marketing-The missing half of the marketing programme," Long Range Plann., vol. 24, no. 2, pp. 82-93, Apr. 1991, doi: 10.1016/0024-6301(91)90083-Z. 
[45] G. D. Harrel and M. F. Fors, "Internal Marketing of a Service," Ind. Mark. Manag., vol. 21, no. 4, pp. 299-306, 1992.

[46] J. Martin, Culturs in Organizational: Three Perspectives. New York: Oxfod University Press, 1992.

[47] M. Rafiq and P. K. Ahmed, "Using the 7Ps as A Generic Marketing Mix: An Exploratory Survey of UK and European Marketing Academics," Mark. Intell. Plan., vol. 13, no. 9, pp. 4-15, 1995.

[48] S. P. Robbins and T. A. Judge, Organizational Behavior. New Jersey: Pearson Educational Inc, 2015.

[49] M. O. R. A. Patah, S. M. Radzi, R. Abdullah, A. Adzmy, R. A. Zain, and N. Derani, "The Influence of Psychological Empowerment on Overall Job Satisfaction of Front Office Receptionists," Int. J. Bus. Manag., vol. 4, no. 11, Oct. 2009, doi: 10.5539/ijbm.v4n11p167.

[50] A. Yahaya, N. Yahaya, K. Arshad, J. Ismail, S. Jaalam, and Z. Zakariya, "Occupational Stress and its Effects towards the Organization Management," J. Soc. Sci., vol. 5, no. 4, pp. 390-397, Apr. 2009, doi: 10.3844/jssp.2009.390.397.

[51] A. Ismail and N. Zakaria, "Relationship between Interactional Justice and Pay for Performance as an Antecedent of Job Satisfaction: an Empirical Study in Malaysia," Int. J. Bus. Manag., vol. 4, no. 3, Feb. 2009, doi: 10.5539/ijbm.v4n3p190.

[52] A. S. Santhapparaj, J. Srinivasan, and K. L. Ling, "Job Satisfaction among Woman Managers in Malaysian Automobile Manufacturing Sector," J. Appl. Sci., vol. 5, no. 9, pp. 1553-1558, Sep. 2005, doi: 10.3923/jas.2005.1553.1558.

[53] F. Noordin and K. Jusoff, "Levels of Job Satisfaction amongst Malaysian Academic Staff," Asian Soc. Sci., vol. 5, no. 5, Apr. 2009, doi: 10.5539/ass.v5n5p122.

[54] E. S. K. Wong and T. N. Heng, "Case Study of Factors Influencing Jobs Satisfaction in Two Malaysian Universities," Int. Bus. Res., vol. 2, no. 2, Mar. 2009, doi: 10.5539/ibr.v2n2p86.

[55] A. K. M. Masum, Md. A. K. Azad, and L.-S. Beh, "Determinants of Academics' Job Satisfaction: Empirical Evidence from Private Universities in Bangladesh," PLOS ONE, vol. 10, no. 2, p. e0117834, Feb. 2015, doi: 10.1371/journal.pone.0117834.

[56] E. Abasi, R. Mohammadipour, and M. Aidi, "An Investigation of the Impact of
Organizational Justice Dimensions on Job Satisfaction (Case Study: An Iranian Bank)," Univers. J. Manag., p. 6, 2014.

[57] A. Bakhshi, K. Kumar, and E. Rani, "Organizational justice perceptions as predictor of job satisfaction and organization commitment," Int. J. Bus. Manag., vol. 4, no. 9, pp. 145-154, Aug. 2009, doi: 10.5539/ijbm.v4n9p145.

[58] T. (Terry) Kim, W. G. Kim, and H.-B. Kim, "The effects of perceived justice on recovery satisfaction, trust, word-of-mouth, and revisit intention in upscale hotels," Tour. Manag., vol. 30, no. 1, pp. 51-62, Feb. 2009, doi: 10.1016/j.tourman.2008.04.003.

[59] L. N. Jewell and M. Siegall, Psikologi Industri/Organisasi Modern: Psikologi Penerapan Untuk Memecahkan Berbagai Masalah Di Tempat Kerja, Perusahaan, Industri, Dan Organisasi, 2nd ed. Jakarta: Arcan, 1998.

[60] C. Moorman, G. Zaltman, and R. Deshpande, "Reliationships Between Providers and Users of Market Research: The Dinamics of Trust within and between Organizations," J. Mark. Res., vol. 29, pp. 314-328, 1992.

[61] T. W. Gruen, J. O. Summers, and F. Acito, "elationship Marketing Activities, Commitment, dan Membership Behaviors inProfesional Associations," J. Mark., vol. 64, no. 3, pp. 34-49, 2000.

[62] J. P. Meyer and N. J. Allen, Commitment in the Workplace: Theory, Research and Application. Thousand Oaks, CA: Sage Publication, 1997.

[63] H. Brooks, The Typology of Surprises in Technology, Institution and Development. Cambridge: Cambridge Univsersity Press, 1986.

[64] V. M. Veličković et al., "Organizational commitment and job satisfaction among nurses in Serbia: A factor analysis," Nurs. Outlook, vol. 62, no. 6, pp. 415-427, 2014, doi: 10.1016/j.outlook.2014.05.003.

[65] I. Azman and A. R. M. Ridwan, "The Effect of Job Satisfaction on Organizational Commitment and," Manag. Mark., vol. XIV, no. 1, 2016, doi: 10.13140/RG.2.1.4082.3280.

[66] U. Sekaran, Metode Penelitian Untuk Bisnis. Jakarta: Salemba Empat, 2003.

[67] J. F. Hair, R. E. Anderson, R. L. Tatham, and W. C. Black, Multivariate Data Analysis, 6th ed. New Jersey: Pearson Educational Inc, 2006. 
[68] I. Ghozali and K. A. Kusumadewi, Model Persamaan Struktural. Semarang: Yoga Pratama, 2017.

[69] Jogiyanto, Konsep dan Aplikasi Sructural Equation Modeling (SEM) berbasis Varian dalam Penelitian Bisnis. Yogyakarta: UPP STIM YKPN, 2011.

[70] W. Chin, "Partial least squares is to LISREL as principal components analysis is to common factor analysis," Technol. Stud., vol. 2, Jan. 1995.

[71] W. W. Chin and A. Gopal, "Adoption intention in GSS: relative importance of beliefs," ACM SIGMIS Database DATABASE $A d v$. Inf. Syst., vol. 26, no. 2-3, pp. 42-64, May 1995, doi: 10.1145/217278.217285.

[72] E. Aykan and E. Sönmez, "Mediating Role of Perceived Organizational Justice between Internal Marketing Practices and Employee Task and Contextual Performance: A Shopping Center Implication," Int. J. Manag. Stud. Res., vol. 2, no. 7, pp. 1-15, 2014.

[73] A. S. Ferdous and M. Polonsky, "The impact of frontline employees' perceptions of internal marketing on employee outcomes," $J$. Strateg. Mark., vol. 22, no. 4, pp. 300-315, Jun. 2014, doi: 10.1080/0965254X.2013.876077.

[74] G. Hogg, S. Carter, and A. Dunne, "Investing in People: Internal Marketing and Corporate Culture," J. Mark. Manag., vol. 14, no. 8, pp. 879-895, Nov. 1998, doi: 10.1362/026725798784867563.

[75] B. Collins and A. Payne, "Internal marketing: A new perspective for HRM," Eur. Manag. J., vol. 9, no. 3, pp. 261-270, Sep. 1991, doi: 10.1016/0263-2373(91)90006-C.
[76] P. Tansuhaj, D. Randall, and J. McCullough, "A Services Marketing Management Model: Integrating Internal and External Marketing Functions," J. Serv. Mark., vol. 2, no. 1, pp. 31-38, Jan. 1988, doi: 10.1108/eb024714.

[77] M. Z. Cohen, L. M. Holley, S. P. Wengel, and R. M. Katzman, "A Platform for Nursing Research on Spirituality and Religiosity: Definitions and Measures," West. J. Nurs. Res., vol. 34, no. 6, p. 24, 2009.

[78] J. Barling and M. Phillips, "Interactional, Formal, and Distributive Justice in the Workplace: An Exploratory Study," $J$. Psychol., vol. 127, no. 6, pp. 649-656, Nov. 1993, doi: 10.1080/00223980.1993.9914904.

[79] L. B. Bingham, "Mediating Employment Disputes: Perceptions of Redress at the United States Postal Service," Rev. Public Pers. Adm., vol. 17, no. 2, pp. 20-30, Apr. 1997, doi: $10.1177 / 0734371$ X9701700203.

[80] T. R. Tyler and E. A. Lind, "A Relational Model of Authority in Groups," in Advances in Experimental Social Psychology, vol. 25, New York: Elsevier, 1992, pp. 115-191.

[81] A. O. Agho, C. W. Mueller, and J. L. Price, "Determinants of Employee Job Satisfaction: An Empirical Test of a Causal Model," Hum. Relat., vol. 46, pp. 1007-1027, 1993, doi: http://dx.doi.org/10.1177/001872679304600 80.

[82] D. J. Dude, "Organizational commitment of principals: The effects of job autonomy, empowerment, and distributive justice," $\mathrm{PhD}$, University of Iowa, Iowa City, Iowa, USA, 2012.

\section{Creative Commons Attribution License 4.0 (Attribution 4.0 International, CC BY 4.0)}

This article is published under the terms of the Creative Commons Attribution License 4.0

https://creativecommons.org/licenses/by/4.0/deed.en_US 